\title{
Towards better work in China: mapping the relationships between high- performance work systems, trade unions, and employee well-being
}

Cite as: Yang, W., Nawakitphaitoon, K., Huang, W., Harney, B., Gollan, P. J., \& Xu, C. Y. 2019. Towards better work in China: mapping the relationships between high-performance work systems, trade unions, and employee well-being. Asia Pacific Journal of Human Resources, 57(4): 553-576.

\begin{abstract}
Human resource management (HRM) is a major mechanism to realise decent work and achieve employee well-being in China. Key questions concern how and when HRM is mutually beneficial for employers and employees, particularly how well HRM works with trade unions in achieving decent work. This study examines the effect of high-performance work systems and trade unions on employee engagement, paying particular attention to the role of industrial relations (IR) climate in facilitating this relationship. Hypotheses were tested via unique cross-sectional survey data from a large employer-employee matched dataset collected from 264 manufacturing firms and 6921 workers in China. The findings highlight that HPWS are a key mechanism for realising decent work. We also find positive evidence for the mutual gains of decent work illustrating the combined impact of HPWS and trade unions in achieving higher levels of employee engagement. Notably, a co-operative (as opposed to adversarial) IR climate is seen to reinforce this relationship, indicating the significance of the quality of relationships among management, employees, and unions in shaping employee outcomes. Overall, these findings advance understanding of the realisation of decent work and 'mutual gains' in a Chinese context.
\end{abstract}

Keywords: employee participation, employee well-being, high-performance work systems, trade unions in China 


\section{Key points:}

1. HPWS are a key mechanism for realising decent work, while the collective voice function of the trade union in China remains insufficient.

2. Greater levels of employee engagement and decent work are achieved when employees experience the combined influence of both HPWS and trade unions.

3. A co-operative industrial relations climate, as reflected in the perceived quality of relationships among management, employees, and unions plays a critical role in enabling and enhancing mutual benefits

Discussions on the nature of work and decent working conditions are increasingly common (Dundon and Rafferty 2018; Osterman 2018). The concept of 'decent work' refers to 'requiring basic security for all - in society, in the workplace and for individual workers', with the primary focus on 'basic income security and basic 'voice' or representation security' (Bonnet, Figueiredo and Standing 2003, 213-214). In the HRM literature, high-performance work systems (HPWS) have been presented as a key means by which more decent working conditions can be achieved to the benefit of both employees (Takeuchi, Chen and Lepak 2009) and employers (Combs et al. 2006). Proponents of HPWS draw on the logic of ability-motivation-opportunity (AMO) which sees the benefits of sophisticated HR practices channelled to develop employee skills (A), enhance employee motivation (M) and provide an opportunity $(O)$ for employees to contribute and realise their potential (Jiang et al. 2012). Yet while intuitively appealing, the HPWS argument has also been subject to criticism. Ongoing debates relate to the limited traction and diffusion of HPWS across workplaces and geographies (universal or unique?), a contradictory impact on workers (beneficial or brutal?), and an uncertain relationship between HPWS and trade unions (complement or cannibalise?) (see Jensen, Patel and Messersmith 2013; Liu et al. 2009; Osterman 2018 respectively).

These fault lines of debate resonate in the context of China where the concept of decent work and how it can be best achieved have similarly come to the fore. Specifically, 
decent work is increasingly demanded by a new generation of Chinese workers who have a raised awareness of labour rights and have been increasingly active in mobilising for greater pay, better working conditions, and more respect from employers (Elfstrom and Kuruvilla 2014; Warner and Zhu 2018). Second, the Chinese government has committed to realising decent work, at least in principle. The creation of employment and improving the quality of employment are central to China's development aspirations as demonstrated in 13th Five Year Plan (FYP). A key priority of the Decent Work Country Programme for China 2016-2020 (ILO 2017) is to strengthen the rule of law and to realise fundamental principles and rights at work. Third, multinational enterprises (MNEs) and global corporate social responsibility (CSR) campaigns have pressured Chinese suppliers to comply with voluntary codes of conduct, uphold labour standards and realise decent work in their workplaces (Yu 2015).

At the workplace and individual worker levels, HRM is seen as a major mechanism to realise decent work and achieve the outcome of employee well-being in Chinese enterprises. Alternative mechanisms to decent work, i.e. enterprise-level trade unions and collective bargaining, are impotent in China (Chan 2014; Chen 2009), while the right to strike has not been clearly stipulated (Chang and Cooke 2015). HR practices are thereby the primary means to determine wages and working conditions in Chinese workplaces. In the long-term, higher labour standards are likely to yield greater productivity, product innovation and adaptability to changing markets (Osterman 2018). Achieving higher labour standards requires companies to adopt sustainable HRM practices which fully utilise the skills of the workforce and enhance high performance, as per the logic of AMO (Kochan and Osterman 1994). The notion of a HPWS claims that a bundle of mutually reinforcing work practices leads to superior organisational performance (Boxall and Macky 2009). The mutual gain perspective of HPWS suggests that individuals and organisations both benefit from HRM. The question is how and when HPWS is mutually beneficial, so that employees can benefit from improved HR practices (Boxall 2012). 
In exploring these issues this paper makes a number of contributions. First, we examine the impact of HPWS in a Chinese context, redressing the western bias of existing research (Bainbridge et al. 2017). Some have found evidence for a universal benefit of HPWS both for firms entering China (Bjorkman and Fan 2002) and for indigenous Chinese firms (Huang, Ma and Meny 2017). Others have been more cautious and pointed to specific cultural and contextual considerations likely to shape HRM (see Zhang 2012). The impact of HPWS in China therefore remains an open question, especially with respect to decent work and working conditions for employees (Cooke 2014). To address this question we use a unique dataset of employer and employee matched responses, thereby overcoming concerns of partial or biased representations of HPWS (Geare et al. 2014). Critically, our emphasis is on employee well-being in the form of employee engagement as opposed to narrow and distal measures of organisational performance (Boxall, Guthrie and Paauwe 2016). This enables us to directly explore the role of HPWS in fostering decent work and working conditions for employees.

Our second contribution builds on the mutual gains perspective by delving into the critical, but often neglected, contextual conditions shaping the impact of HR on employee well-being (Guest 2017). Particularly significant here is the role of the trade union as framed by the changing nature of labour and employment relations and the emergence of collectivism in China. In response to the upsurge in labour unrest and external challenges arising from the global CSR campaign and the proactive activities of labour non-government organisations (NGOs; Huang et al. 2016), the All-China Federation of Trade Unions (ACFTU), the only official trade union in China, has initiated reforms to enhance its representation (Qiao 2017). Given the new trends in industrial relations (IR) in China in recent decades (Brown and Chang 2017), it is imperative to examine the relationship between HPWS and the trade union in China and their interaction in achieving decent work and positive outcomes for Chinese employees. While some suggest that trade unions enhance the use of HPWS and therefore offer the potential of 'mutual gains' for both employees and organisations (Kochan and Osterman 1994), others have pointed to a relationship

Please cite as: Yang, W., Nawakitphaitoon, K., Huang, W., Harney, B., Gollan, P. J., \& Xu, C. Y. 2019. Towards better work in China: mapping the relationships between high-performance work systems, trade unions, and employee well-being. Asia Pacific Journal of Human Resources, 57(4): 553-576. 
which is 'equivocal' at best (Liu et al. 2009). We contribute to the mutual gains perspective of HRM by elaborating and empirically investigating the role of trade unions in the HPWS - employee well-being relationships

Our third contribution extends understanding of employee perceptions of an IR climate. IR climate refers to 'the atmosphere, norms, attitudes, and behaviours reflecting and underpinning how workers, unions, managers interacted collectively with each other in the workplace, which in turn, affects workplace outcomes' (Pyman et al. 2010, 463). Valizade et al. (2016) suggest that a positive IR climate is an enabling mechanism for the process of mutual gains. In particular, a co-operative IR climate has been found to be linked to better organisational performance (Boxall and Macky 2009). The literature on the relationship between HRM, employee well-being, and organisational performance also includes IR climate in the relationship dimension of employee well-being (van de Voorde, Paauwe and van Veldhoven 2012). Relatively few studies examine the impact of IR climate on employee and organisational outcomes in a non-western context, particularly in China. We add to IR climate contributions by incorporating management and employee perceptions, while expanding the discussion beyond considerations of employee voice (cf Pyman et al. 2010) to more broadly encompass HPWS. Drawing on social exchange theory (SET; Blau 1964; Eisenberger et al. 1997), a higher level of employee engagement reinforces the achievements of decent work efforts via HPWS and the trade union. A more positive IR climate facilitates the connection between HPWS and employee engagement.

As per the conceptual scheme in Figure 1, this paper explores the relationship between HPWS, trade unions, IR climate, and employee engagement. It views HPWS and trade union as two distinctive mechanisms to realise decent work, and in turn enhance employee well-being at work. We further examine whether a co-operative IR climate will enable and enhance such mutual benefits. In the next section, we develop key hypothesis before detailing the matched employer-employee survey and detailing key findings and implications.

Please cite as: Yang, W., Nawakitphaitoon, K., Huang, W., Harney, B., Gollan, P. J., \& Xu, C. Y. 2019. Towards better work in China: mapping the relationships between high-performance work systems, trade unions, and employee well-being. Asia Pacific Journal of Human Resources, 57(4): 553-576. 


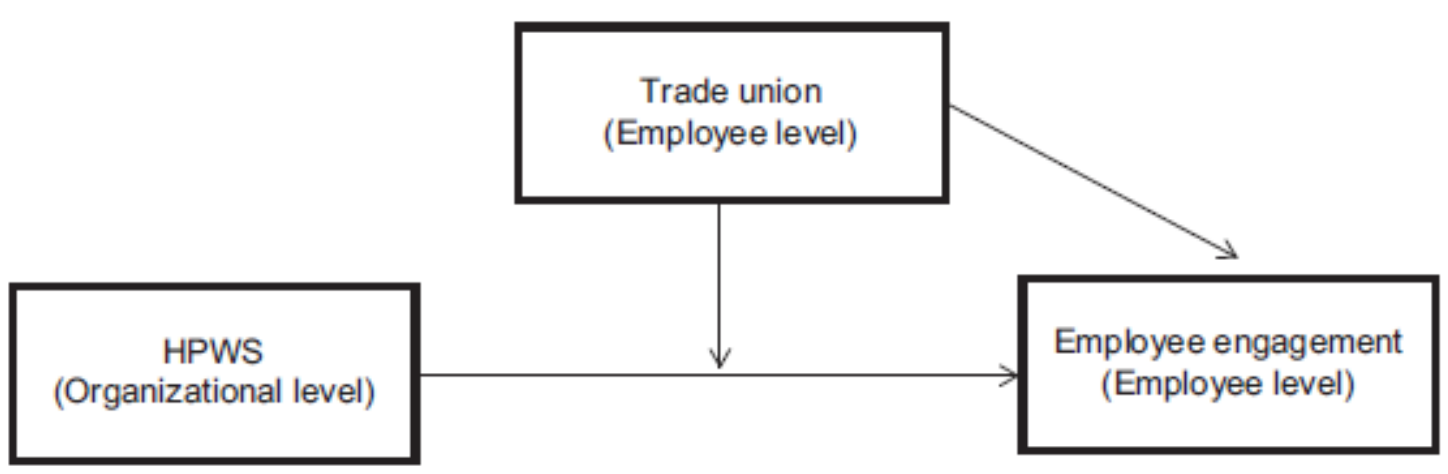

IR climate

(Employee level)

\section{Literature review and hypotheses development}

\section{HPWS and employee engagement}

HPWS constitute 'systems of human resource practices designed to enhance employee's skills, commitment and productivity in such a way that employees become a source of competitive advantage' (Datta, Guthrie and Wright 2005, 135). While the precise labels vary, HPWS typically include sophisticated selection, extensive training and appraisal, communication and empowerment, performance rewards and employment security. Extensive reviews highlight the proliferation of HPWS research (Bainbridge et al. 2017), but also evidence a narrow focus on organisational performance. Where employee perceptions and outcomes such as well-being have been incorporated, this has been in the service of realising optimal performance rather than as a valuable end in and of itself (Guest 2017; Marchington 2015). Appreciating employee outcomes and decent work is an important concern, as research has pointed to prospective 'dark side' of HPWS including increased work intensification and job demands (Godard 2004; Jensen, Patel and Messersmith 2013).

Research on HPWS in China has been similarly motivated to demonstrate organisational

Please cite as: Yang, W., Nawakitphaitoon, K., Huang, W., Harney, B., Gollan, P. J., \& Xu, C. Y. 2019. Towards better work in China: mapping the relationships between high-performance work systems, trade unions, and employee well-being. Asia Pacific Journal of Human Resources, 57(4): 553-576. 
performance benefits. Reflecting a convergence thesis, there is some support for the universal impact and the cross-national validity of HPWS (see reviews by Kim, Wright and Su 2010; Liang, Marler and Cui 2012). For example, Bjorkman and Fan (2002) found that HPWS had a positive and significant impact on firm performance for foreign-owned companies in China. Focusing on the hospitality sector in China, Sun, Aryee and Law (2007) similarly found a positive impact of HPWS on firm-level turnover and productivity. By contrast, a divergence thesis opens up questions related to the applicability of HPWS in China, including the dynamics of their diffusion and the likely interaction with employee experience and the institutional and cultural backdrop (Zhang 2012). For example, it could be the case that the Chinese high-power distance culture may limit the benefits of autonomy and the potential for self-directed teams as stressed by HPWS. On the other hand, the reciprocity embedded in the Chinese guanxi society may actually mean employees reward such approaches with greater engagement and effort (Huang, Ma and Meny 2017). What is clear is that employee outcomes are frequently assumed or neglected. The dominant approach to strategic HRM research in China focuses on ways to improve performance, while neglecting the 'reality' of practices (Warner and Zhu 2018) in the form of employee well-being and decent work

To explore employee experiences of HPWS we draw on the concept of employee engagement (Bailey 2016). Notably, we move beyond engagement understood in a narrow sense as a psychological state of mind related to feelings, cognitions, and behaviours of individuals towards their work (Saks 2006). While this approach has been dominant (Schaufeli et al. 2002) it has contributed to the individualisation and psychologisation of HRM, hollowing out understanding from its broader context (Godard 2014). Instead, we align with emerging work which examines engagement as workforce management strategy (Bailey 2016), and considers engagement as a management practice (Bailey et al. 2017); 'doing engagement' in contrast with 'being engaged' (Truss et al. 2014). Conceptualising employee engagement with the organisation, as opposed to with employees' work and job, is likely to be more meaningful for both scholarly understanding and practical application 
(Reissner and Pagan 2013). Research in this vein has predominantly consisted of qualitative case studies (Arrowsmith and Parker 2013; Reissner and Pagan 2013).This stream of work is founded on social exchange theory, emphasising the norm of reciprocity as a core feature of exchange relations to explain the engagement process: when employees interpret HR practices as indicative of organisational support and care for them, they are more likely to reciprocate in turn to their organisation, with raised levels of engagement (Bailey et al. 2017; Saks 2006, 603). Recent research points to the merits of examining the HPWS - employee engagement relationship in a Chinese context. Drawing on data from 782 employees Huang, Ma and Meny (2017) found a positive impact of HPWS on employee attitudes and subsequently engagement, albeit narrowly understood. Warner and Zhu (2018) and Huang et al. (2018) suggest that the 'new generation' of Chinese employees are more independent and open and are therefore likely to be receptive to HPWS. We therefore propose that:

Hypothesis 1: Perceived HPWS is positively related to employee engagement in the Chinese Context

\section{Trade unions and employee engagement}

In general, employees who are offered chances to voice their opinions and express their concerns are likely to feel valued and involved, which enhances their engagement (Beugr e 2010; Reissner and Pagan 2013). The existence of voice can heighten employee engagement, which in turn leads to behaviours that are likely to improve organisations (Beugr e 2010, 177). Empirical research findings from two UK service sector organisations (Rees, Alfes and Gatenby 2013) shows that employees with positive perceptions of voice opportunities are more engaged. Qualitative research in a public-private partner organisation in the United Kingdom demonstrates that employee voice is one of the most important antecedents of employee engagement (Reissner and Pagan 2013). Notably, however, studies on the association between trade union representation as a form of voice and employee 
attitudinal outcomes, particularly employee engagement, are scarce. Previous studies in western and other settings of the union - organisational commitment relationship reveal mixed results (Hammer and Avgar 2005). In China, most empirical studies focus on the Chinese union effect with respect to economic outcomes like wages, benefits, employment, and productivity (Budd et al. 2014; Yao and Zhong 2013), while ignoring employee well-being and work-related outcomes.

One of the main theoretical frameworks to explain the relationship between union representation and employee outcomes is Freeman and Medoff's (1984) two faces of union model. The monopoly face suggests that trade unions act like monopolies that distort labour markets by raising wages above competitive levels, causing firms to lower employment and output. This, in turn, harms overall economic efficiency. In addition, unions tend to limit management's ability to operate the enterprise, create a more adversarial relationship between employees and employers, reduce workplace flexibility, and abate the work enthusiasm of employees. This is likely to result in lower discretion and engagement with the organisation. By contrast, the collective voice face suggests that trade union representative voice conveys employee input to management, which is then able to improve employment conditions in line with employee preferences and, therefore, raise employee satisfaction and engagement. Indeed, from this perspective trade unions could be viewed as a manifestation of the employer's commitment to employee welfare.

Questions exploring the trade union - employee engagement relationship are especially significant in China given the emergence of collective labour relations (Brown and Chang 2017). Empirical research suggests that Chinese workers have a strong tendency to identify their union with the employing organisation (Chan et al. 2006). The Chinese trade union has initiated reforms to enhance its representational functions. A recent case study of 12 manufacturing foreign-invested enterprises highlights a management strategy of 'co-optation' resulting in a 'company union', going beyond traditional welfare functions 
to act as a communication channel dealing with individual and collective labour disputes, presenting employees' views and engaging in negotiation with management (Chan et al. 2017). Employees reciprocate to the organisation with heightened engagement. The benefits to the company are the retention of employees and reduction in the cost of recruitment. Discussions also draw on the reality of a collectivist culture in China, likely to promote the collective good as opposed to individual aspirations. We therefore hypothesise the following:

Hypothesis 2: Trade union membership is positively related to employee engagement with their organisation in the Chinese context

\section{Interactive effect of HPWS and trade unions on employee engagement}

Research reveals that the relationship between HPWS and trade unions is contested and equivocal (Liu et al. 2009). Early critiques claimed HRM represented a deliberate attempt by management to individualise the employment relationship at the expense of any collective representation (Dundon, Harney and Cullinane 2010). Fiorito, Lowman and Nelson

(1987) found that the likelihood of establishing a trade union was significantly reduced where HPWS were in place. By contrast, others have concluded that exemplars of HRM are not any more likely to exhibit resistance to trade union recognition (Kochan and Osterman 1994), with some finding evidence of complementary interactions between HPWS and trade unions (Machin and Wood 2005). Researching HPWS in Ireland Liu et al. (2009) found that increased trade union representation was associated with a decrease in HPWS use. In terms of employee outcomes and decent work, research from a national sample of Canadian firms finds support for a complementary thesis whereby employees represented by trade unions and subject to more extensive coverage of high involvement practices experience fewer intensification pressures, less unpaid overtime, reduced grievances while also reporting higher levels of job satisfaction (Pohler and Luchak 2014). The above results reflect the key debate in the literature of whether the 
HPWS - trade union relationship is a substitutive or complementary one. The substitution thesis views HPWS as outweighing or diminishing the requirement for trade unions either as a result of the benefits accrued from HPWS and/or because of staunch antiunionism (Dundon, Harney and Cullinane 2010). The alternative compatibility thesis is founded on a mutual gains perspective focusing on the alignment of HPWS and trade union intent, e.g. as related to fairness, due process and highlighting employee skills development, etc. (Kochan and Osterman 1994). Overall, there still remains a paucity of research examining the extent to which the existence and the involvement of unions in workplaces facilitate the adoption of HPWS and lead to more 'mutual gains' (Harley 2014). Moreover, the nature of interactions between HPWS and trade unions is likely to vary across countries, with China providing a new context to re-examine this relationship.

Extensive reviews of the link between HPWs and organisational performance in the Chinese context (e.g. Liang, Marler and Cui 2012) have payed limited or no attention to the role of trade unions. This is equally the case for research which has explored the relationship between HPWS and employee outcomes (e.g. Cooke et al. 2016; Zhang and Morris 2014). For example, Sun, Aryee and Law (2007) draw on a relational perspective to open the black box of HPWS and employee outcomes, exploring contextual moderators of unemployment and business strategy. The neglect of trade unions is perhaps understandable considering that HRM largely appeared in China via MNEs in the early 1990s, while trade unions have historically played a limited role at the workplace. Yet the recent 'sea-change' in employment and labour relations (Warner and Zhu 2018), and the emergence of collective labour relations (Chang and Brown 2013) make exploration of the HPWS - trade union interaction a critical topic. Increased trade union density and collective bargaining coverage accompany a shift towards 'grass-root' interests (see Zhu, Warner and Feng 2011). This takes place against a backdrop of pressure from top political leaders and an upsurge in labour unrest, global CSR campaigns, and proactive activities of labour NGOs (Huang et al. 2016; Qiao 2017).

Please cite as: Yang, W., Nawakitphaitoon, K., Huang, W., Harney, B., Gollan, P. J., \& Xu, C. Y. 2019. Towards better work in China: mapping the relationships between high-performance work systems, trade unions, and employee well-being. Asia Pacific Journal of Human Resources, 57(4): 553-576. 
While respective literature has studied HPWS and union representation in China, there remains a lack of appreciation of the prospective interaction between these two. The promise of HPWS under a 'mutual gains' paradigm suggests benefits for employers, workers and their trade unions (Godard 2004, 349). Beugr_e (2010) has noted the requirement to explore the nature of voice channels, especially the extent to which multiple channels can be associated with heightened employee engagement (see also Pyman et al. 2010, 471). In China, the trade union is expected by the party-state and practitioners to make more use of its face of collective voice, functioning as an additional avenue to complement individual voice mechanisms of HPWS, and thereby recognise employee interests and enhance organisational performance (Chan et al. 2017). By the same token, the trade union in China may not be the same substitute for HPWS as their counterparts in western countries, due to the 'double identity' of the Chinese trade union (Chen 2003), protecting worker interests and national interests. We therefore hypothesise that:

Hypothesis 3: A complementary interaction will be observed between HPWS and trade unions, such that employee engagement will be higher where both HPWS and a trade union are present

\section{The role of IR climate}

A positive IR climate is an enabling mechanism for the process of mutual gains (Valizade et al. 2016). Explorations of IR climates have moved from an exclusive focus on 'unionmanagement' relations to reflect broader 'organisational members' including both employee-management and employee-union relations (Pyman et al. 2010). Research has shown that IR climates impact both employee and organisational outcomes (Boxall and Macky 2009; Dastmalchian 2008). Deery, Iverson and Erwin (1999) found that IR climate is positively associated with job performance, while the quality of employee, union and management relationships was linked to enhanced commitment. Drawing on data from 305 branches of a unionised Australian-based MNC, Deery and Iverson (2005) found that the perception of a co-operative IR climate was related to greater employee commitment.

Please cite as: Yang, W., Nawakitphaitoon, K., Huang, W., Harney, B., Gollan, P. J., \& Xu, C. Y. 2019. Towards better work in China: mapping the relationships between high-performance work systems, trade unions, and employee well-being. Asia Pacific Journal of Human Resources, 57(4): 553-576. 
A co-operative IR climate has a direct impact on employee engagement by promoting a mutual gain relationship between management and its members. In line with SET, a cooperative IR climate can be perceived by employees as an employers' intention to create a climate for a positive employment relationship (Guest 2017). It is seen as the employer's input to mutuality (where the organisation and employees have common goals) in exchange for heightened employee engagement with the organisation. We therefore hypothesise that:

Hypothesis 4: A co-operative IR climate is positively related to employee engagement.

In the western context, a co-operative IR climate has been found to function as an enabler for unionised organisations to adopt HPWS (Godard 2004; Liu et al. 2009). In addition, some scholars (e.g. B_elanger and Edwards 2007; Edwards, B_elanger and Wright 2006) claim that under a co-operative IR climate it is likely that HPWS will be introduced in ways that 'deliver "mutual gains" in the form of improved productivity and enhanced quality of working life' (Harley 2014, 86). In the context of China, when the IR climate is co-operative, employers are perceived to create a co-operative and participatory climate. The trade union then becomes an effective channel of collective voice, combined with the individual voice channel inherent in HPWS. A stronger voice in decision-making makes it likely that employees will reciprocate by demonstrating higher levels of engagement with their organisation than those in an adversarial IR climate. Co-operative employer - union relationships and mutual gains practices are likely to result in beneficial outcomes (Kochan and Osterman 1994). By contrast, in a less co-operative IR climate, the trade union is set up purely to comply with the legislative requirement, resulting in 'paper unions' or 'welfare unions' (Chan et al. 2017). Therefore, we hypothesise that the effect of HPWS and the trade union on employee engagement would be stronger under a collaborative IR climate than that under an adversarial IR climate.

Hypothesis 5: Under a co-operative IR climate, the interactive effect of HPWS and trade

Please cite as: Yang, W., Nawakitphaitoon, K., Huang, W., Harney, B., Gollan, P. J., \& Xu, C. Y. 2019. Towards better work in China: mapping the relationships between high-performance work systems, trade unions, and employee well-being. Asia Pacific Journal of Human Resources, 57(4): 553-576. 
unions on employee engagement is more positive than that under the adversarial IR climate.

\section{Methods}

In contrast to research in this area which has focused exclusively on managerial (Liu et al. 2009) or employee (Pyman et al. 2010) respondents, we address calls for an integrative, multi-level appreciation drawing on both managerial and employees perceptions (Kim, Wright and Su 2010).

\section{Data collection}

The researchers collected data from one of China's regional industrial parks in December 2014. The local labour and social security bureau provided a list of companies. Our selection criterion for companies was those employing more than 100 employees - 701 companies met this criterion and participated in the survey. We used online survey software in China, and sent out HR and employee surveys to the companies via e-mails, a webpage link and QR code. With the online survey software, we could monitor the length of time that participants spent on completing the survey. To avoid superficial responses, those who completed it below a reasonable length of time were removed and not included in the analysis. This was considered practical to ensure data quality. We asked the companies to print out the messages for the employee survey with the relevant QR code, and to post them in a prominent position in the workplace, (e.g. bulletin boards, cafeteria or entrance). Employees could scan the QR code using their mobile phone or click the webpage link in the e-mail to access the survey. The HR manager survey included the questions on HR practices and organisational performance. The employee survey focused on their work experience at the organisation.

A total of 325 companies (46\% response rate) returned the survey, and 7411 employees from 264 companies completed the employee survey. We restricted our sample to workers aged between 18 and 65, and after deleting feedback with missing information on key variables, our final sample size was 6921 workers, which is a relatively high number 
compared to other datasets relating to HR in China, and indeed HRM research generally (Bainbridge et al. 2017).

\section{Variables}

High-performance work system

It is important to acknowledge that there is lack of definitional consensus on what constitutes a HPWS and its key component practices (Zhang and Morris 2014). The HPWS measure used in this study follows the multi-dimensional scale used by Kochan and Osterman (1994). In the employer survey, the HR manager was asked to indicate the level of agreement on 8 items using a 5-point Likert scale (1 = 'strongly disagree' and 5 = 'strongly agree') based around the following statement: 'Consider the last 12 months, whether you agree with the following statement, regarding your company's HRM policies.' Specifically, the 8 items measured consisted of business strategy, top management style, employee participation in strategy making and governance, staffing and job security, payment systems, employee selection, broad task design and teamwork, and employee involvement in problem-solving. Sample items included 'The company staffing policy is designed to reinforce employees' job security', 'The company's performance pay system can reinforce cooperation, participation, and contribution', and 'Employees and their representatives have the opportunity to participate in problem-solving and decision-making in terms of work and working conditions'. The HPWS score was generated by averaging across all 8 items to create a composite measure. Higher scores indicated a higher level of HPWS adopted in the company. We also conducted a confirmatory factor analysis (CFA) to test their validity. The results showed that all items had acceptable loadings to the factor ranging from 0.52 to 0.81 . The internal reliability of this measure (Cronbach's alpha) was 0.89 .

Trade union

In order to capture the reality of employee experiences which can differ markedly from management assertions (Geare et al. 2014), we use the measure of trade union membership

Please cite as: Yang, W., Nawakitphaitoon, K., Huang, W., Harney, B., Gollan, P. J., \& Xu, C. Y. 2019. Towards better work in China: mapping the relationships between high-performance work systems, trade unions, and employee well-being. Asia Pacific Journal of Human Resources, 57(4): 553-576. 
from the employee survey. Specifically, employees responded to the question

'Are you a member of an employee union?' Then, we constructed a dichotomous variable, taking a value of 1 if the employee was a union member and 0 otherwise.

\section{Employee engagement}

Employee engagement is measured using the established 6-item scale from the voice project at Macquarie University (see Langford 2010). The attitudinal measures of employee engagement include job satisfaction, organisational commitment, and intention to stay. For each item, employees were asked to indicate their level of agreement using a 5-point Likert scale ( $1=$ 'strongly disagree', and 5 = 'strongly agree'). Sample items included 'I am proud to tell people that I work for this organisation', 'I feel a sense of loyalty and commitment to this organisation', 'My work gives me a feeling of personal accomplishment', 'I like the kind of work I do'. Employee desire and intent to remain at this employer were measured by two items. The items were summed and averaged to create a single measure. Higher scores indicated a higher level of employee engagement. Cronbach's alpha for the employee engagement was 0.96 .

\section{IR climate}

Our measure of IR climate is similar to that used by Pyman et al. (2010), which asked employees about the quality of relationships between management and employees. However, we expand this to also consider employee perceptions about the quality of workplace relationships between unions and employees, and management and unions. In particular, three items were used from the employee survey to assess the level of IR climate. For each item, employees were asked to indicate their level of agreement using a 5-point Likert scale $(1=$ 'strongly disagree', and 5 = 'strongly agree'). These 3 items included 'In general, the relations between management and employees are good,' 'In general, the relations between management and unions are good,' and 'In general, the relations between unions and employees are good.' These items were summed and averaged to create a single measure. Higher scores indicated higher levels of IR climate. Cronbach's 
alpha for IR climate was 0.94 . We then created a dichotomous variable representing the level of IR climate, which took a value of 1 if an employee's scores on these 3 items were greater than 3 and 0 otherwise.

\section{Control variables}

Following previous research, and to alleviate the concern of omitted variable bias, we incorporated both employee and company characteristics that might influence organisational commitment as our control variables. Specifically, our control variables for employee characteristics included age, gender, education level, years of tenure, working position, and employment status. For example, age consisted of six categories: 'under 20', '20-29', '30-39', '40-49', ‘50-59', and '60 or older'. Education had five possible categories: 'high school', 'certificate or diploma', 'college degree', and 'master's degree or higher'. The control variable for the company characteristic was the size of company, quantified by the sum of all regular salaried employees in the company.

\section{Analyses and results}

Descriptive statistics and hypothesis testing

Table 1 presents the descriptive statistics for the main variables in the study. In particular, approximately $47 \%$ of employees reported that they were a trade union member. Fiftyone per cent of employees in this sample were female. In terms of age profile, $1.4 \%$ were $<20$ years old, $45.5 \%$ were between 20 and 29 years old, $42.7 \%$ were between 30 and 39 years old, $8.9 \%$ were between 40 and 49 years old, $1.5 \%$ were above 50 years old. In terms of work tenure, $30.8 \%$ of respondents had $<2$ years' tenure in the organisation, $34.5 \%$ had 2 to 5 years' tenure, $25.5 \%$ has 5 to 10 years' tenure and $9.2 \%$ had more than 10 years' tenure. For education, $10.7 \%$ of respondents had a secondary school qualification or below, $37.6 \%$ had diploma or equivalent degree, $48.2 \%$ had a Bachelor's Degree, 3.5\% had a Masters or PhD. In terms of working positions, $58.7 \%$ of respondents were frontline employees, $26.9 \%$ were line managers, $11.6 \%$ were middle managers and $2.7 \%$

Please cite as: Yang, W., Nawakitphaitoon, K., Huang, W., Harney, B., Gollan, P. J., \& Xu, C. Y. 2019. Towards better work in China: mapping the relationships between high-performance work systems, trade unions, and employee well-being. Asia Pacific Journal of Human Resources, 57(4): 553-576. 
were senior managers or executives. For employer characteristics, the participating organisations in the survey varied in terms of size ranging from 15 to 7800 employees, while the average firm size was 880 employees

Table 2 provides the bivariate correlations among the key variables of this study. In particular, HPWS was positively and significantly correlated with employee engagement $(r=0.104, p<0.05)$. This indicates that employees employed in a company adopting a high rate of HR practices were more likely to be committed and engaged with their organisation. Similarly, the correlation between IR climate and employee engagement was also positive and statistically significant $(r=0.750, p<0.05)$, implying that employees with a perception of high quality of the relations among unions, employees, and employers were more likely to have a high level of employee engagement. On the other hand, union membership was negatively and significantly correlated with employee engagement $(r=0.03, p<0.05)$ and IR climate $(r=0.06, p<0.05)$. This implies that union members were less likely to be engaged with their organisation, and reported a lower level of quality of workplace relations than their non-union counterparts. Most of the correlations among other variables are in the expected direction. Details are contained in Table 2.

Table 2 Correlations among the key variables

\begin{tabular}{lllllll}
\hline & $\begin{array}{l}\text { Employee } \\
\text { engagement }\end{array}$ & $\begin{array}{l}\text { Union } \\
\text { membership }\end{array}$ & HPWS & $\begin{array}{l}\text { IR } \\
\text { climate }\end{array}$ & $\begin{array}{l}\text { Firm } \\
\text { size }\end{array}$ & Female \\
\hline $\begin{array}{l}\text { Employee } \\
\quad \text { engagement }\end{array}$ & 1.000 & & & & & \\
$\begin{array}{l}\text { Union } \\
\text { membership }\end{array}$ & $-.031^{*}$ & 1.000 & & & & \\
HPWS & $.104^{*}$ & .002 & 1.000 & & & \\
IR climate & $.749^{*}$ & $-.066^{*}$ & $.086^{*}$ & 1.000 & & \\
Firm size & $.044^{*}$ & .023 & $.128^{*}$ & .020 & 1.000 & \\
Female & -.016 & .017 & $-.050^{*}$ & .013 & .010 & 1.000 \\
\hline${ }^{*} p<0.05$. & & & & & &
\end{tabular}

Please cite as: Yang, W., Nawakitphaitoon, K., Huang, W., Harney, B., Gollan, P. J., \& Xu, C. Y. 2019. Towards better work in China: mapping the relationships between high-performance work systems, trade unions, and employee well-being. Asia Pacific Journal of Human Resources, 57(4): 553-576. 
To test our main hypotheses, we applied a moderated hierarchical regression analysis using ordered probit regression. In particular, we included HPWS and union membership variables to test their direct effects on employee engagement. We then inserted the interaction term of HPWS and union membership variables to examine their interactive effect.

Note that this study examines the cross-level effect in which the main predictor, HPWS, is at one level of analysis while the outcome variable, employee engagement, is at a different level of analysis. In particular, the mean scores of organisational HPWS were assigned to each individual respondent in the organisation. The regression results are presented in

Table 3.

Table 3

Table 3 Regression results (ordered probit)

\begin{tabular}{|c|c|c|c|c|c|c|}
\hline Independent variables & 1 & SD & 2 & SD & 3 & SD \\
\hline $\begin{array}{l}\text { Union } \\
\text { membership }(0 / 1)\end{array}$ & -.034 & .026 & $-.509+* 4$ & .226 & .028 & .026 \\
\hline HPWS & $.220+4 *$ & .027 & $.164^{*+*}$ & .037 & $.192^{*+*}$ & .026 \\
\hline HPWS ×Union & & & $.110^{* *}$ & .052 & & \\
\hline IR climate $(0 / 1)$ & & & & & $1.742^{*+*}$ & .043 \\
\hline ln(firm size) & $.046^{+* *}$ & .012 & $.0471^{* * *}$ & .012 & $.044^{*+*}$ & .012 \\
\hline Female $(0 / 1)$ & -.026 & .026 & -.026 & .026 & $-.086^{*+*}$ & .026 \\
\hline \multicolumn{7}{|l|}{ Age (years) } \\
\hline $20-29$ & .087 & .121 & .075 & .120 & $.071^{*}$ & .115 \\
\hline $30-39$ & .145 & .123 & .133 & .122 & .106 & .118 \\
\hline $40-49$ & $A 01^{* * *}$ & .128 & $.387^{*+*}$ & .128 & $.337^{* * *}$ & .124 \\
\hline $50-59$ & $.575^{*+*}$ & .176 & $.556^{* * *}$ & .176 & $.463^{*+*}$ & .173 \\
\hline 60 or older & 300 & .274 & .286 & .275 & $A 98^{* *}$ & .234 \\
\hline \multicolumn{7}{|l|}{ Tenure (years) } \\
\hline $2-5$ & $-0.088^{* * *}$ & .032 & $-.086^{* * 4}$ & .032 & $-.067^{* 4}$ & .033 \\
\hline $5-10$ & $-.128 * 4 *$ & .038 & $-.128 * * *$ & .038 & $-.079 * *$ & .038 \\
\hline 10 or more & $-.091^{*}$ & .054 & -.095 & .054 & -.055 & .053 \\
\hline Certificate $(0 / 1)$ & $.156^{*+*}$ & .043 & $.155^{*+*}$ & .043 & $.140^{*+*}$ & .044 \\
\hline College $(0 / 1)$ & $.218^{*+*}$ & .045 & $.217^{* * *}$ & .045 & $.138^{* * *}$ & .045 \\
\hline $\begin{array}{l}\text { Master or } \\
\qquad \operatorname{PhD}(0 / 1)\end{array}$ & .116 & .080 & .111 & .080 & .004 & .083 \\
\hline Full-time $(0 / 1)$ & .048 & .065 & .046 & .065 & .047 & .064 \\
\hline Part-time $(0 / 1)$ & .085 & 312 & .078 & .313 & -.089 & 358 \\
\hline Casual (0/1) & $.275^{*}$ & .150 & $.287^{*}$ & .150 & $313^{* *}$ & .145 \\
\hline Supervisor $(0,1)$ & $-.129 * * *$ & .045 & $-.132 * * *$ & .046 & $-.118^{*+*}$ & .046 \\
\hline Executive $(0 / 1)$ & $357^{*+*}$ & .084 & $.357^{* * *}$ & .084 & $327^{*+*}$ & .085 \\
\hline $\begin{array}{l}\text { Frontline } \\
\text { worker }(0 / 1)\end{array}$ & $-.210^{*+*}$ & .046 & $-.214^{* * *}$ & .046 & $-.201^{* * *}$ & .046 \\
\hline \#Observations & 6921 & 6921 & 6921 & 6921 & 6921 & 6921 \\
\hline
\end{tabular}

${ }^{*} p<0.10,{ }^{* *} p<0.05,{ }^{* * *} p<0.01$. $z$-statistics are in the parentheses. Reference groups indude: Age ( $<20$ years old), Tenure ( $<2$ years), Education (high school), Employment status (fixed-term), Working position (middle manager). 
Column 1 included HPWS and union membership, as well as the control variables in the regression to test their direct effects on employee engagement. The result showed that organisation-level HPWS was positively and significantly associated with employee-level employee engagement $(b=0.220, p<0.001)$. This supports our proposed hypothesis 1 . On the other hand, union membership had an insignificant association on employee engagement, holding the characteristics of employees and organisation constant $\left(b=\_0.034, p>0.10\right)$. Hence, there is no evidence that employee engagement is affected by whether or not employees are union members. Note: this is not to say that the effect of union membership is zero, but rather that its effect is trivial or negligible. Hypothesis 2 was therefore not supported. In addition, we also observed significant relationships between the control variables and employee engagement. As is common in engagement research, older groups of employees were more likely to report engagement with their organisation than the youngest group of workers ( $<20$ years old). On average, employees who completed college or received diploma degrees had a higher level of employee engagement than those who had completed education at high school level. The size of organisation also had a positive and significant relationship with employee engagement $(b=0.046, p<0.001)$, implying that employees employed in a large company were more likely to have higher employee engagement than those in a small company. Contrarily, there is no significant difference of employee engagement between fixed-term contract workers and other type workers. Column 2 showed the interactive effect of HPWS and union membership on employee engagement. The result indicated that the interaction term was positively and statistically significant $(b=0.110, p<0.050)$. This supports hypothesis 3 , implying that HPWS contributed more positive employee engagement among union members than non-union members. Column 3) included the IR climate condition into the regression. The result showed that the higher the level of perception of a co-operative IR climate, the more significantly positive the effect on employee engagement $(b=1.74, p<0.001)$, thereby supporting our proposed hypothesis 4 . 
Table 4 presents the separation of regression results of HPWS and union membership under both high and low IR climates, which we label co-operative and adversarial IR climates, respectively. The results showed that the direct effect of HPWS on employee engagement was positive and statistically significant under a highly rated IR climate $(b=0.215, p<0.001)$, but not under a lowly rated IR climate $(b=0.012, p>0.10)$. Similarly, the interactive effect of HPWS and union membership on employee engagement was positive and nearly significant at a $5 \%$ level under a highly rated, co-operative IR climate $(b=0.109, p=0.057)$, but becomes statistically insignificant under a lowly rated, adversarial IR climate $(b=0.108, p>0.10)$. This supports hypothesis 5 , implying the important role of employee perceptions of IR climate in influencing the effect of HPWS and union membership on employee engagement.

Table 4

Table 4 Regression results by the level of industrial relations climate

\begin{tabular}{|c|c|c|c|c|c|c|c|c|}
\hline \multirow[t]{2}{*}{ Independent variables } & 1 & SD & 2 & SD & 3 & SD & 4 & $\mathrm{SD}$ \\
\hline & \multicolumn{4}{|c|}{ High IR climate } & \multicolumn{4}{|c|}{ Low IR climate } \\
\hline Union membership $(0 / 1)$ & .032 & .028 & $-.437^{*}$ & .247 & -.039 & .073 & -.500 & .585 \\
\hline HPWS & $.215^{*+4}$ & .029 & $.160 * * *$ & .041 & .012 & .070 & -.045 & .095 \\
\hline HPWS $\times$ Union & & & $.109^{*}$ & .057 & & & .108 & .137 \\
\hline $\ln$ (firm size) & $.046^{* * *}$ & .012 & $.047^{* * *}$ & .012 & .013 & .037 & .014 & .037 \\
\hline Female $(0 / 1)$ & $-.109^{*+*}$ & .028 & $-.109 * *+$ & .028 & .098 & .073 & .102 & .073 \\
\hline \multicolumn{9}{|l|}{ Age (years) } \\
\hline $20-29$ & .012 & .132 & .000 & .131 & .275 & .254 & .268 & .253 \\
\hline $30-39$ & .055 & .134 & .043 & .133 & $.262^{* 4}$ & .264 & .251 & .263 \\
\hline $40-49$ & $.269^{*}$ & .139 & $.255^{*}$ & .138 & $.749^{* * *}$ & .307 & $.742^{* *}$ & .306 \\
\hline $50-59$ & $.445^{* *}$ & .185 & $.427^{* * *}$ & .184 & .275 & .663 & .242 & .666 \\
\hline 60 or older & $.548^{*}$ & .290 & $.538^{*}$ & .290 & .664 & .418 & .642 & 420 \\
\hline \multicolumn{9}{|l|}{ Tenure (years) } \\
\hline $2-5$ & $-.072^{* *}$ & .035 & $-.071^{* *}$ & .035 & .017 & .091 & .018 & .090 \\
\hline $5-10$ & $-.087^{* *}$ & .041 & $-.086^{* *}$ & .041 & -.012 & .104 & -.010 & .105 \\
\hline 10 or more & -.061 & .057 & -.065 & .056 & .033 & .170 & .033 & .170 \\
\hline Certificate $(0 / 1)$ & $.157^{*+*}$ & .047 & $.156^{* * *}$ & .047 & .067 & .115 & .065 & .114 \\
\hline College $(0 / 1)$ & $.182^{* * *}$ & .049 & $.182^{* * *}$ & .049 & -.144 & .115 & -.147 & .115 \\
\hline Master or $\mathrm{PhD}(0 / 1)$ & .027 & .086 & .023 & .086 & -.119 & .306 & -.128 & .306 \\
\hline Fulltime $(0 / 1)$ & .012 & .067 & .010 & .067 & .238 & .189 & .239 & .190 \\
\hline Partime $\left(\alpha_{1}\right)$ & -.124 & .347 & -.132 & 349 & .000 & - & .000 & - \\
\hline Casual $(0 / 1)$ & $.313^{* *}$ & .161 & $323 * *$ & .161 & 382 & .346 & .398 & .351 \\
\hline Supervisor $(0 / 1)$ & $-.109^{* *}$ & .048 & $-.112^{* *}$ & .048 & -.177 & .156 & -.177 & .156 \\
\hline Executive $(0 / 1)$ & $.333^{*+*}$ & .087 & $332^{* * *}$ & .087 & .244 & .442 & .252 & $A 44$ \\
\hline Frontline worker $(0 / 1)$ & $-.186^{* 4 t}$ & .049 & $-.191 * * *$ & .049 & $-.288^{*}$ & .151 & $-.290^{*}$ & .151 \\
\hline \#Observations & 6111 & & 6111 & & & 810 & & 810 \\
\hline
\end{tabular}

${ }^{*} p<0.10,{ }^{* *} p<0.05,{ }^{* * *} p<0.01$. 


\section{Discussion and conclusions}

China represents an 'interesting and important context' to re-examine and extend the debate on the impact of HPWS (Chan and He 2018, 403). Studies have moved to unlock the black box of HR-performance causal links by exploring the relationship between HPWS and employee outcomes (e.g. Cooke et al. 2016; Zhang and Morris 2014), but have not directly explored decent work or the role of trade unions. Advancing such understanding is of critical significance as China is witnessing the emergence of collective relations and faces bottom-up and top-down pressures for economic and social upgrading (Brown and Chang 2017; Chan and He 2018). Our study stresses the significance of complementary interaction between HPWS and the trade union in achieving decent work. In exploring this topic we extend previous research which has focused exclusively on managerial (Liu et al. 2009) or employee (Pyman et al. 2010) respondents.

Overall, we find support for a positive and significant impact of perceived HPWS on employee engagement. This result is consistent with many previous studies, mostly in a western setting, and supports the theory that the adoption of western HR practices can improve employee outcomes in the context of China (Huang, Ma and Meny 2017; Qiao, Khiljib and Wang 2009). Following the premise of social exchange theory, where organisations adopt HPWS and invest in human capital and employee well-being, employees in turn reciprocate with heightened engagement. While we found limited evidence for a direct relationship between trade unions and engagement, when combined with HPWS we find evidence for a compatibility impact (Machin and Wood 2005); when both HPWS and trade unions are in place more heightened employee engagement is more likely. Support for the compatibility thesis advances our knowledge based on the realisation of decent work and 'mutual gains', while also indicating that the collective voice function of the trade union remains insufficient. The interactive HPWS - trade union effect means we caution against overly simplistic universal or convergence

Please cite as: Yang, W., Nawakitphaitoon, K., Huang, W., Harney, B., Gollan, P. J., \& Xu, C. Y. 2019. Towards better work in China: mapping the relationships between high-performance work systems, trade unions, and employee well-being. Asia Pacific Journal of Human Resources, 57(4): 553-576. 
thesis interpretations of the impact of HPWS (Zhang 2012) as these can neglect critical contextual or boundary conditions. Our third key finding demonstrates that IR climate plays an important role in influencing the effect of HPWS and union membership on employee engagement, extending these insights to the Chinese context (Pyman et al. 2010). Specifically, under a co-operative IR climate, the interactive effect of HPWS and union membership is positive and statistically significant while under an adversarial IR climate the interaction effect is statistically insignificant. This provides evidence that the extent to which HPWS and/or the trade union lead to positive employee outcomes is contingent on the quality of management, employees, and union relationships. This finding highlights importance of a co-operative IR climate as a contributor to positive employee attitudes, validating Boxall, Guthrie and Paauwe's (2016) assertion that HRM well-being research can be advanced via valuable sources of theory from IR/ER.

Our study offers convincing evidence that the achievement of decent work via HPWS and trade unions can bring about mutual gains, benefiting both employees and the organisation (van de Voorde, Paauwe and van Veldhoven 2012, 392). HPWS are therefore a key mechanism of achieving decent work in Chinese workplaces (Cooke 2017). Despite recent reforms the trade union influence is likely to be insufficient to drive decent working conditions for employees. Operating in tandem, HPWS and trade unions can serve to enhance mutual gains, facilitated by an underlying co-operative IR climate.

\section{Practical implications}

This study has significant practical implications. Chinese employees are reported to have very low levels of engagement (Huang, Ma and Meny 2017) coupled with raising expectations related to work and working conditions (Warner and Zhu 2018). In this context, our study shows that employees under a high rate of HPWS are more likely to report a high level of engagement with their organisation. Organisations should adopt HPWS practices in their workplace to enhance employee engagement and well-being. Second, it 
offers employers convincing evidence for the role of mutual gains in realising decent work. Third, the analysis reveals that the direct and interactive effects of HPWS and the trade union are contingent on the IR climate. Therefore, organisations should carefully build and manage a good rapport and relationship with employees and the trade union (Grant, Christianson and Price 2007); enhancing the industrial relations climate should be a desired outcome of employers (Pyman et al. 2010). Indeed, our evidence suggests that in addition to HPWS, the quality of the relationship with the union and employees also impacts the level of employee engagement with the organisation. Considering the complementary nature of the trade union in China's workplaces and the significance of the IR climate, organisations should leave more space for developing the collective voice function of the trade union, and integrate the union into decision-making systems, so that the union can attain legitimacy and recognition from its members, thereby enabling HPWS to fully realise its potential.

\section{Limitations and future research direction}

There are some limitations to this study. First, because the survey data comes mainly from manufacturing organisations in one city, the sample may not be fully representative of Chinese enterprises and employees. Therefore, future studies should collect data from other industries and regions in China. Second, as with many other empirical studies, the employer-employee survey is a cross-sectional dataset, which means assertions of causality are limited. However, this study has advanced previous work by incorporating both HR manager, and employee data. Ultimately, longitudinal surveys are needed to confirm

the causality of the relationship. Finally, employee interpretations of their supervisors' behaviours and intentions play a large role in shaping employee attitudes and behaviours. When employees perceive their supervisor's HR-related actions to be supportive or focused on improving their performance, they likely will reciprocate those actions with higher job satisfaction and commitment, more discretionary effort, and greater productivity (Harney and Jordan 2008). Therefore, to fully understand the relationship between HPWS and employee engagement, it is important to appreciate line managers' intentions when implementing HPWS, and employees' perceptions of same.

Please cite as: Yang, W., Nawakitphaitoon, K., Huang, W., Harney, B., Gollan, P. J., \& Xu, C. Y. 2019. Towards better work in China: mapping the relationships between high-performance work systems, trade unions, and employee well-being. Asia Pacific Journal of Human Resources, 57(4): 553-576. 


\section{References}

Arrowsmith J, J Parker (2013) The meaning of 'employee engagement' for the values and roles of the HRM function. The International Journal of Human Resource Management 24 (14), 2692-2712.

Bailey C (2016) Employee engagement: Do practitioners care what academics have to say - And should they? Human Resource Management Review https://doi.org/10.1016/j.hrmr.2016.12.014

Bailey C, A Madden, K Alfes and L Fletcher (2017) The meaning, antecedents and outcomes of employee engagement: A narrative synthesis. International Journal of Management Reviews 19 (1), 31-53.

Bainbridge H, K Sanders, J Cogin, and C H Lin (2017). The pervasiveness and trajectory of methodological choices: A 20- year review of Human Resource Management Research. Human Resource Management, 56 (6), 887-913

Bélanger J, P Edwards (2007) The conditions promoting compromise in the workplace. British Journal of Industrial Relations 45 (4), 713-734.

Beugré C D (2010) Organizational conditions fostering employee engagement: the role of "voice". In: Albrecht S L (ed.) Handbook of employee engagement: Perspectives, issues, research and practice. Cheltenham, Edward Elgar.

Bjorkman I, and X C Fan (2002) Human resource management and the performance of Western firms in China. International Journal of Human Resource Management,

13(6), 853-864.

Blau PM (1964) Exchange and power in social life. John Wiley \& Sons, New York.

Bonnet F, J B Figueiredo and G Standing (2003) A family of decent work indexes. International Labour Review 142, 213-238.

Boxall P, (2012) High-performance work systems: what, why, how and for whom? Asia Pacific Journal of Human Resources 50 (2), 169-186.

Boxall P, K Macky (2009) Research and theory on high-performance work systems: Progressing the high involvement stream. Human Resource Management Journal 19, 3-23.

Boxall P, J Guthrie, and J Paauwe, J. (2016) Editorial introduction: Progressing our understanding of the mediating variable linking HRM, well-being and organisational performance. Human Resource Management Journal 26(2), 103-111.

Brown W A, K Chang (2017) The emerging industrial relations of China. Cambridge University Press, Cambridge.

Budd J, W Chi, Y Wang and Q Xie (2014) What do unions in China do? Provincial-level evidence on wages, employment, productivity, and economic output. Journal of Labor Research 35, 185-204.

Please cite as: Yang, W., Nawakitphaitoon, K., Huang, W., Harney, B., Gollan, P. J., \& Xu, C. Y. 2019. Towards better work in China: mapping the relationships between high-performance work systems, trade unions, and employee well-being. Asia Pacific Journal of Human Resources, 57(4): 553-576. 
Chan A W, E Snape, M S Luo and Y Zhai (2017) The developing role of unions in China's foreign-invested enterprises. British Journal of Industrial Relations 55 (3), 602-625.

Chan A W, T Q Feng, T Redman and E Snape (2006) Evaluating the multi-dimensional view of employee commitment: a comparative UK-Chinese study. International Journal of Human Resource Management 17, 1873-1887.

Chan C K C (2014) Constrained Labour Agency and the Changing Regulatory Regime in China. Development and Change 45, 685-709.

Chan C K C and Y He (2018) The transformation of employment relations in contemporary China, Chapter 25 in The Routledge Companion to Employment Relations, eds A Wilkinson, T Dundon, J Donaghey, and A Colvin A, 402-417. Routledge, Oxford.Chang K, F L Cooke (2015) Legislating the right to strike in China: Historical development and prospects. Journal of Industrial Relations 57 (3), 440455.

Chang K, W Brown (2013) The transition from individual to collective labour relations in China. Industrial Relations Journal 44 (2), 102-121.

Chen F (2003) Between the state and labour: The conflict of Chinese Trade Unions' double identity in market reform. The China Quarterly 176, 1006-1028.

Chen F (2009) Union Power in China: Source, Operation, and Constraints. Modern China 35, 662-689.

Combs J G, D Ketchen, A Hall, and Y Liu (2006) Do high performance work practices matter? A metaanalysis of their effects on organisational performance. Personnel Psychology, 59, 501-528.

Cooke F L (2014) Chinese industrial relations research: In search of a broader analytical framework and representation. Asia Pacific Journal of Management 31(3), 875-898.

Cooke F L (2017) Decent work, decent industrial relations and decent social relations: the case of China in perspectives. 5th Conference of the Regulating for Decent Work Network. Geneva.

Cooke F L, B Cooper, T Bartram, J wang and H Mei (2016) Mapping the relationships between highperformance work systems, employee resilience and engagement: a study of the banking industry in China. The International Journal of Human Resource Management, 1-22.

Dastmalchian A (2008) Industrial relations climate. In The SAGE handbook of industrial relations. edsBlyton P, N Bacon, J Fiorito and E Heery London, Sage.

Datta D, J Guthrie and P Wright (2005) Human Resource Management and Labor Productivity: Does Industry Matter? Academy of Management Journal 48(1), 135-145.

Deery S J, R D Iverson and P J Erwin (1999) Industrial relations climate, attendance behavior and the role of trade unions. British Journal of Industrial Relations 37 (4), 533-558.

Deery S J, R D Iverson (2005) Labour-management cooperation and its impact on organizational performance. Industrial and Labor Relations Review 58, 588-610.

Dundon T and A Rafferty (2018) The (potential) demise of HRM? Human Resource Management Journal, 10.1111/1748-8583.12195

Please cite as: Yang, W., Nawakitphaitoon, K., Huang, W., Harney, B., Gollan, P. J., \& Xu, C. Y. 2019. Towards better work in China: mapping the relationships between high-performance work systems, trade unions, and employee well-being. Asia Pacific Journal of Human Resources, 57(4): 553-576. 
Dundon, T, B Harney, and N Cullinane (2010) 'De-collectivism and managerial ideology: towards an understanding of trade union opposition' International Journal of Management Concepts and Philosophy. 4(3/4): 267-281.

Edwards P, J Bélanger and M Wright (2006) The bases of compromise in the workplace: A theoretical framework. British Journal of Industrial Relations 44(1), 125-145.

Eisenberger R, J Cummings, S Armeli and P Lynch (1997) Perceived organizational support, discretionary treatment, and job satisfaction. Journal of Applied Psychology 82, 812-820.

Elfstrom M, S Kuruvilla (2014) The changing nature of labor unrest in China. Industrial \& Labor Relations Review 67, 453-480.

Fiorito J, C Lowman and F Nelson. F. (1987) The Impact of Human Resource Policies on Union Organizing Industrial Relations, 26 (1), 113-26.

Freeman R B, J L Medoff (1984) What do unions do? New York, Basic Books.

Geare A, F Edgar, I McAndrew, B Harney, K Cafferkey and T Dundon (2014) Exploring the ideological undercurrents of HRM: Workplace values and beliefs in Ireland \& New Zealand. International Journal of Human Resource Management 25(16), 2275-2294.

Godard J (2004) A critical assessment of the high-performance paradigm. British Journal of Industrial Relations 42 (2), 349-378.

Godard, J. (2014) The psychologisation of employment relations? Human Resource Management Journal. 24(1): 1-18.

Grant A M, M K Christianson and R H Price (2007) Happiness, health, or relationships? Managerial practices and employee well-being tradeoffs. Academy of Management Perspectives 21, 51-63.

Guest D E (2017) Human resource management and employee well-being: towards a new analytic framework. Human Resource Management Journal 27 (1), 22-38.

Hammer T H, A Avgar (2005) The impact of unions on job satisfaction, organizational commitment and turnover. Journal of Labor Research 26, 241-266.

Harley N (2014) ref xxxxxxxxx

Harney B, C Jordan (2008) Unlocking the black box: Line managers and HRM performance in a call centre context. International Journal of Productivity and Performance Management. 57(4), 275-296.

Huang W, Y Li, S Wang and J Weng (2016) Can 'democratic management' improve labour relations in market-driven China? Asia Pacific Journal of Human Resources 54, 230-257.

Huang Y, Ma Z, Meny Y (2017) High-performance work systems and employee engagement: empirical evidence from China, Asia Pacific Journal of Human Resource Management, doi:10.1111/17447941.12140

Please cite as: Yang, W., Nawakitphaitoon, K., Huang, W., Harney, B., Gollan, P. J., \& Xu, C. Y. 2019. Towards better work in China: mapping the relationships between high-performance work systems, trade unions, and employee well-being. Asia Pacific Journal of Human Resources, 57(4): 553-576. 
Huang, Y F, Fan D, Su Y Y, and Wu, T L (2018). "High Performance Work Systems, Dual Stressors and 'New Generation' Employee in China." Asia Pacific Business Review. doi:10.1080/13602381.2018.1451127.

ILO (2017). Decent Work Country Programme for China 2016-2020. International Labour Organization. http://www.ilo.org/beijing/what-we-do/publications/WCMS_549135/lang--en/index.htm (acessed 6 February 2018).

Jensen, J, P C Patel, and J Messersmith (2013) High Performance Work Systems and Job Control: Consequences for Anxiety, Role Overload, and Turnover Intentions. Journal of Management, 39(6), 1699-1724.

Jiang K, D Lepak, J Hu and J Baer (2012) How does human resource management influence organizaional outcomes? A meta-analytic investigation of mediating mechanisms. Academy of Management Journal 55(6), 1264-1294.

Kim, S., Wright, P M., Su., Z. (2010) Human resource management and firm performance in China: A critical review, Asia Pacific Journal of Human Resource Management, 48(1): 58-85.

Kochan T A, and Osterman P (1994) The mutual gains enterprise: forging a winning partnership among labor, management, and government. Harvard University Press, Boston.

Langford P H (2010) The nature and consequences of employee engagement: searching for a measure that maximizes the prediction of organizational outcomes. In: Albrecht S L (ed.) Handbook of employee engagement : perspectives, issues, research and practice. Cheltenham, Edward Elgar.

Liang X, J H Marler And Z Cui (2012) Strategic human resource management in China: east meets west. The Academy of Management Perspectives 26, 55-70.

Liu W, J P Guthrie, P C Flood and S MacCurtain (2009) Unions and the adoption of high performance work systems: Does employment security play a role? Industrial and Labor Relations Review 63(1), 109-127.

Machin S, S Wood (2005) Human resource management as a substitute for trade unions in British workplaces. ILR Review 58, 201-218.

Marchington, M (2015) Human resource management (HRM): Too busy looking up to see where it is going longer term?. Human Resource Management Review, 25(2) 176-187.

Osterman, P. (2018) In search of the high road: meanings and evidence. Industrial and Labor Relations Review 71(1), 3-34.

Pohler, D. R. and Luchak, A. (2014) 'Balancing efficiency, equity, and voice: The impact of unions and High-Involvement Work Practices on work outcomes', Industrial Industrial and Labor Relations Review, 67(4), 1063-1094

Pyman A, P Holland, J Teicher and B K Cooper (2010) Industrial relations climate, employee voice and managerial attitudes to unions: an Australian study. British Journal of Industrial Relations, 48, 460480 .

Please cite as: Yang, W., Nawakitphaitoon, K., Huang, W., Harney, B., Gollan, P. J., \& Xu, C. Y. 2019. Towards better work in China: mapping the relationships between high-performance work systems, trade unions, and employee well-being. Asia Pacific Journal of Human Resources, 57(4): 553-576. 
Qiao J (2017) Trade union reform: "quality and efficiency" of the path of socialist trade union with Chinese characteristics-The reform of Shanghai mass organizations in 2016. Journal of China Institute of Industrial Relations, 31, 72-83.

Qiao K, S Khiljib and X Wang (2009) High-performance work systems, organizational commitment, and the role of demographic features in the People's Republic of China. The International Journal of Human Resource Management 20, 2311-2330.

Rees C, K Alfes and M Gatenby (2013) Employee voice and engagement: connections and consequences. The International Journal of Human Resource Management 24, 2780-2798.

Reissner S, V Pagan (2013) Generating employee engagement in a public-private partnership: management communication activities and employee experiences. The International Journal of Human Resource Management 24, 2741-2759.

Saks A M (2006) Antecedents and consequences of employee engagement. Journal of Managerial Psychology 21, 600-619.

Schaufeli W B, M Salanova, V González-Romá and A B Bakker (2002) The measurement of engagement and burnout: A two sample confirmatory factor analytic approach. Journal of Happiness Studies 3, 7192.

Sun LY, S Aryee, and K Law (2007) High-performance human resource practices, citizenship behavior, and organisational performance: A relational perspective. Academy of Management Journal 50(3), 558-577.

Takeuchi, H., Chen, G., and Lepak, D. P. (2009). Looking through the looking glass of a social system: Cross level effects of HPWS on employees' attitudes Personnel Pyschology, 62: 1-29.

Truss C, R Delbridge, K Alfes, A Shantz and E Soane (2014) Employee engagement in theory and practice. London, Routledge.

Valizade D, C Ogbonnaya, O Tregaskis and C Forde (2016) A mutual gains perspective on workplace partnership: Employee outcomes and the mediating role of the employment relations climate. Human Resource Management Journal 26, 351-368.

Van De Voorde K, J Paauwe and M Van Veldhoven (2012) Employee well-being and the HRMorganizational performance relationship: A review of quantitative studies. International Journal of Management Reviews, 14, 391-407.

Warner, M and Y Zhu (2018) The challenges of managing 'new generation' employees in contemporary China: setting the scene. Asia Pacific Business Review,

24(4), 429-436, DOI: 10.1080/13602381.2018.1451130

Yao Y, N Zhong (2013) Unions and workers' welfare in Chinese firm. Journal of Labor Economics 31, 633-667.

Please cite as: Yang, W., Nawakitphaitoon, K., Huang, W., Harney, B., Gollan, P. J., \& Xu, C. Y. 2019. Towards better work in China: mapping the relationships between high-performance work systems, trade unions, and employee well-being. Asia Pacific Journal of Human Resources, 57(4): 553-576. 
$\mathrm{Yu}, \mathrm{X}$ (2015) Upholding labour standards through corporate social responsibility policies in China. Global Social Policy 15, 167-187.Zhang, M (2012) The development of human resource management in China: An overview

Human Resource Management Review, 22(3), 161-164.

Zhang B, J L Morris (2014) High-performance work systems and organizational performance: Testing the mediation role of employee outcomes using evidence from PR China. The International Journal of Human Resource Management 25, 68-90.

Zhu Y, M Warner and T Feng (2011) Employment relations "with Chinese characteristics": The role of trade unions in China. International Labour Review 150, 127-143. 